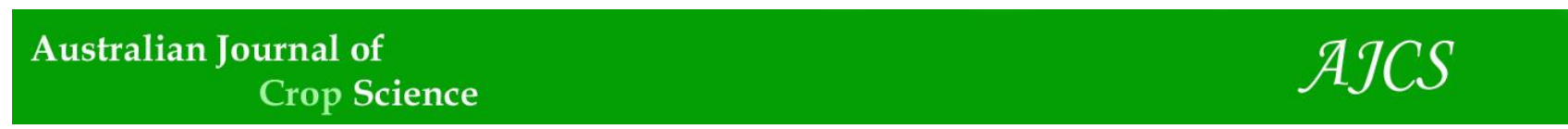

AJCS 12(07):1041-1050 (2018)

ISSN:1835-2707

doi: 10.21475/ajcs.18.12.07.PNE780

\title{
Morphological changes recorded in different phenophases of sugarcane plants subjected to water stress in tropical field conditions
}

\author{
Laurício Endres ${ }^{1 *}$, Claudiana Moura dos Santos ${ }^{1}$, Geraldo Veríssimo de Souza ${ }^{2}$, Marcelo Menossi ${ }^{3}$, \\ Jhulyanne Christiny Marcelino dos Santos ${ }^{1}$
}

${ }^{1}$ Laboratory of Plant Physiology, Center of Agricultural Sciences, Federal University of Alagoas - Campus DelzaGitaí, Br 104 North, Km 85, municipality of Rio Largo, AL, Brazil

${ }^{2}$ Program of Sugarcane Genetic Improvement of the Interuniversity Network for the Sugar Energy Sector Development; Federal University of Alagoas (Ridesa/UFAL), Maceio, AL, Brazil

${ }^{3}$ Laboratory of Functional Genome, Institute of Biology, Campinas State University-UNICAMP, Campinas, SP, Brazil

*Corresponding author: lauricioendres@hotmail.com

\begin{abstract}
Nowadays, water deficit is one of the major environmental stress issues affecting sugarcane crops around the world. It has been causing significant production decrease due to the increased mortality rates generated by water stress in sugarcane plantations. The aim of the current study is to assess sugarcane morphological and yield responses during different phenophases of sugarcane varieties when plants are subjected to drought stress in the fields of a tropical region. Six sugarcane varieties, namely: SP79-1011, RB855113, RB92579, RB867515, RB72454, and RB855536, were subjected to water stress. The herein adopted water regimes were (i) irrigated crop and (ii) crop subjected to natural drought in the field. Plants were cultivated under water stress imposition throughout three phenological stages (i) tillering, three months after planting; (ii) intense growth, seven months after planting; and (iii) ripening, eleven months after planting. The irrigation treatment consisted of supplementing the crop with $50 \mathrm{~mm}$ of water per month during the dry season, whereas non-irrigated plants were naturally grown under water stress conditions throughout the experiment. Water stress mostly affected the sugarcane crop during the intense growth phase. Varieties RB72454 and RB855536 presented smaller green-leaf number, as well as narrower leaf width and smaller leaf area under water stress; besides, they showed low productive potential and high stress susceptibility index (SSI). Stalk height maintenance and the larger number of tillers in RB92579 plants subjected to water stress helped balancing yield rates. This variety also showed the best drought tolerance (DTI) and yield/tolerance indices (YTI); moreover, the principal component analysis evidenced that leaf area, plant height and yield were important factors to distinguish the most tolerant varieties. Such results show that RB92579 is more drought tolerant and has better physiological acclimation potential than the other five varieties; therefore, it can be recommended for crops subjected to drought periods.
\end{abstract}

Keywords: Saccharumspp., stalk, leaf area, yield, drought, phenology.

Introduction

Sugarcane is grown in more than 90 countries distributed in tropical and subtropical regions and its crops cover 26 million hectares worldwide (FAO, 2016); however, Brazil and India hold the largest sugarcane production sites in the world (Waclawovsky et al., 2010). The area in Brazil planted with sugarcane crops for sugar and ethanol production in 2016 covered more than 9 million hectares, which were mostly concentrated in the South-Central and Northeastern regions. Sugarcane production in the country (658.7 million tons) resulted in 34.61 million tons of sugar and in 29.21 billion liters of ethanol (FAO, 2016).

The growing demand for ethanol and sugar has been forcing the sugarcane culture to expand to other Brazilian regions such as the Midwestern, which is covered by Savanna vegetation, (Campos et al., 2014), as well as to marginal areas of the Northeastern region. However, these areas are known for being more exposed to water deficit than the traditional producer regions (Guimarães Cardoso et al., 2015). Nowadays, water deficit is one of the major issues faced even by traditional cropping regions; it affects many sugarcane crops worldwide and is the main yield-limiting factor for them (Endres et al., 2010; Inman-Bamber and Smith, 2012; Gentile et al., 2015; Silva et al., 2015). Besides, stronger drought effects are expected to come due to climate changes and to increased water scarcity, which may further worsen the problem (Zhao and Li, 2015). Northeastern Brazil, which is the traditional sugarcane producer region in the country, has been facing temperature and evapotranspiration rate increase, fact that has been reducing water availability in the soil (Carvalho et al., 2015). The low rainfall rates and poor rainfall distribution in this region led to reduced crop production and to mortality in 
sugarcane crops (Farias et al., 2008; Silva et al., 2013). Therefore, it is worth developing varieties capable of adapting to prolonged drought in order to increase sugarcane production.

Sugarcane phenological stages are characterized by four phenophases, namely: germination, tillering, intense growth, and ripening (Gasho and Shih, 1983). Water deficit impact on the species yield does not depend on water stress intensity, alone; but also on the phenological stage (InmanBamber and Smith, 2005). Sugarcane can endure short drought periods in the ripening stage; however, long-term drought can lead to significant yield and technologicalquality losses (Oliveira et al., 2011; Basnayake et al., 2012; Campos et al., 2014). However, the water deficit effect on sugarcane crops is more severe during the other stages (Smit and Singels, 2006; Begum and Islam, 2012; Inman-Bamber et al., 2012; Zhao et al., 2013). Most drought-stress studies are carried out in pots (Uehara et al., 2009; Thiebaut et al., 2013; Guo et al., 2014; Santos et al., 2015); therefore, it is crucial to better understand the responses of plants subjected to real field conditions.

The principal component analysis (PCA) is a multivariate statistical technique that allows analyzing quantitative variables in different treatments (Bailey, 1959). Studies on different crops such as corn (Sousa Guimarães et al., 2014; Ali et al., 2015) and cocoa (Santos et al., 2014) have applied this statistical method to select the morphological and physiological variables that better classify the factors able to help selecting the most water-stress tolerant genotypes. Therefore, it can be an important tool to assess growth characteristics suitable to classify different varieties according to their drought-tolerance rates.

The yield rate of varieties living in environments subjected to water deficit is a good starting point to identify the genotypes presenting the best potential in sites undergoing rainfall shortage (Anwar et al., 2011; Menezes et al., 2014). Similar to studies with beet (Ober et al., 2004), wheat (Menezes et al., 2011; Anwar et al., 2011) and sorghum (Menezes et al., 2014), stress susceptibility (SSI), drought tolerance (DTI) and yield/tolerance indices (YTI) were the variables chosen to select the most stress tolerant sugarcane varieties. They were useful for the current study to help characterizing the most drought-tolerant sugarcane varieties. The aim of the present study was to assess the morphological and yield responses of sugarcane varieties subjected to water stress in the field during different phenophases.

\section{Results}

\section{Morphological characterization of varieties subjected to drought conditions}

Stalk height was different in the assessed sugarcane varieties in all phenophases (Fig 3A, 3B, and 3C). Water deficit led to mean plant height reduction by $44.5 \%$ in the intense growth phase (Fig 3B). Variety RB855113 recorded the highest reductions (54.0\%) in this phenophase, whereas SP79-1011 presented the lowest reduction (34.8\%) in the same phenophase.

The number of green leaves did not change much in irrigated varieties (Fig 3D, 3E, and 3F); on the other hand, water deficit reduced the number of leaves in the three phenophases, when the mean of all the assessed varieties was taken into account. The number of plants per meter reached its maximum in the intense growth stage, but it decreased afterwards (Fig 3G, 3H, and 3I). Variety RB92579 produced the largest number of plants per meter in all phenophases, whereas RB72454 generated the smallest number of plants. Another interesting result regards the negative effect water stress had on the number of plants per meter in the tillering and intense growth phenophases, as well as its positive effect during the ripening stage.

The leaf length reached its maximum in the ripening stage (Fig 4A, 4B, and 4C), but water stress had negative effect on leaf length during the tillering and intense growth phenophases. There was 29.7 and $27 \%$ reduction in the leaf length of SP79-1011 and RB855536 during the intense growth phenophase, respectively.

The leaves did not reach their full width at the tillering phenophase (Fig 4D, 4E, and F4). Water deficit affected leaf width in the intense growth phenophase of all the assessed varieties. The greatest leaf width reduction was recorded in RB72454 (29.2\%) and RB92579 (25.1\%); there was no effect of this variable on the tillering or ripening stages.There was leaf area index (LAI) decrease in all the phenophases due to water deficit (Fig 4G, 4H, and 4I). Only RB92579 presented statistically significant LAl decrease in the ripening phenophase due to water stress. This variety recorded $55.1 \%$ and $53.2 \%$ LAl decrease due to water stress during the tillering and intense growth phenophases, respectively; however, it presented the highest LAI rates in all phenophases.

The length and diameter of internode +3 were not affected by water stress during the ripening phenophase (Fig $5 \mathrm{~A}, 5 \mathrm{~B})$; there was soluble-solids concentration increase when the mean of all the assessed varieties was taken into account (Fig 5C).

\section{Sugarcane yield and technological quality}

Drought significantly affected the yield of all the assessed varieties, its mean reduction rated $31.5 \%$ when it was compared to the yield of plants grown under irrigation (Table 1). Varieties RB855536 and RB72454 were the most affected by water stress, their yield reached $60.2 \mathrm{t} / \mathrm{ha}^{-1}$ and $54.3 \mathrm{t} / \mathrm{ha}^{-1}$, which corresponds to $35 \%$ and $50 \%$ reduction, respectively.

Varieties RB92579 and RB867515 recorded the highest mean yields under irrigation and water deficit, respectively (Table 1). Variety RB92579 presented stalk yield $128 \mathrm{t} / \mathrm{ha}^{-1}$ under irrigation, and $98.2 \mathrm{t} / \mathrm{ha}^{-1}$ under water stress conditions; whereas RB867515 had stalk yield $125.7 \mathrm{t} / \mathrm{ha}^{-1}$ under irrigation, and $88.5 \mathrm{t} / \mathrm{ha}^{-1}$ under water stress.

Most varieties emerged as high-quality raw materials, even when they were under water stress (Table 1). Variety RB855113 was the only one showing decreased total soluble solid (Brix) and total recoverable sugar (TRS) rates (approximately 9\%) under water stress conditions during the harvest season (Table 1).

\section{Drought tolerance index of the assessed varieties}

Varieties RB92579 and RB855113 recorded the highest drought-tolerance index (DTI), whereas RB72454 and RB855536 presented the lowest DTI (Table 2). Variety RB92579 had the highest yield/tolerance index (YTI); it was followed by RB867515 (Table 2). 

Multivariate analysis of morphological variables in
different phenophases

Leaf area index, green-leaf number and plant height strongly contributed to factor-1 formation during the tillering phenophase (55.8\% PC1 variation) (Fig 6A). Leaf area was the morphological characteristic mostly contributing to variety classification according to water-deficit tolerance. The principal component analysis showed grouping trend in plants subjected to water stress (Fig 6B); however, RB72454 and RB855536 detachment can indicate drought sensitivity during the tillering phenophase. The leaf area index and plant height were the most important variables to factor-1 formation during the intense growth phenophase $(70.26 \%$ PC1 variation) (Fig $6 \mathrm{C}$ ); there were groupings during the phenophase of most of the tolerant varieties. However, RB855536 was outside the group (Fig 6D); therefore, this variety was more sensitive to water stress during this vegetative stage.

The yield and leaf area index were the greatest contributions to factor- 1 formation during the ripening phenophase (37.80\% PC1 variation) (Fig 6E). The grouping analysis applied to varieties subjected to water stress evidenced that RB72454 and RB855536 presented the longest distance from the main axis in SYH and leaf area (Fig $6 \mathrm{E}$ and $6 \mathrm{~F}$ ), and it indicates that they were the least productive varieties under water deficit.

\section{Discussion}

The aim of the current study was to understand the phenological dynamics of different sugarcane varieties subjected to water deficit conditions in the field, as well as to assess how the adaptation to this environmental stress leads to energy losses in detriment to yield. According to Hemaprabha et al. (2013), sugarcane response to water stress is a complex mechanism because of genetic variations within cultivars, as well as of plant growth stage, stress duration and severity.

The studied sugarcane varieties proved to be more susceptible to drought during the intense growth and stalk elongation phenophases, since they recorded stalk height, leaf length, width and area reduction during these phenophases. The sugarcane tillering and intense growth stages (also known as formation phase) have been characterized as critical water-demand periods in the phenological stages (Ramesh and Mahadevaswany, 2000). According to Larcher (2004), plants reach their metabolicactivity peak in the intense growth stage; the phenotypic plasticity characteristics, which feature the adaptation to habitat conditions, manifest themselves at this stage.

Varieties RB855113 and RB855536 were the most affected by water deficit during the intense growth stage and it may have led to yield reduction during the ripening stage. Varieties RB867515 and RB92579 recorded growth rates higher than those of other varieties during the ripening stage, besides achieving yield maintenance, and it suggests that these varieties withstood water stress and had the best development under prolonged drought periods. Silva et al. (2008) subjected 78 sugarcane varieties to water deficit in the field and found that the most tolerant cultivars presented the lowest height reductions. Besides, they observed association between these reductions and high yield rates; according to them, plant height is the variable to be used as sugarcane water-deficit tolerance or susceptibility indicator. The significant height reduction in the most water-stress susceptible sugarcane varieties was also recorded by other authors (Inman-Bamber and Smith, 2005; Machado et al., 2009; Begum and Islam et al., 2012; Hemaprabha et al., 2013).

Water stress caused intense green-leaf number decrease in RB72454 and RB855536 from the tillering to the intense growth stage, and it may indicate their drought sensitivity. This result meets that recorded by Machado et al. (2009), Pincelli and Silva (2012), and Santos et al. (2015), who found significant leaf-number reduction in plants more sensitive to drought in experiments carried out in pots. Furthermore, the rapid leaf senescence observed in sugarcane plants subjected to water stress has been classified as the plants' mechanism to "escape" drought in many studies (InmanBamber, 2004; Inman-Bamber et al., 2012). Leaf number reduction was observed in other studies with sugarcane plants subjected to drought in the field; it is part of the first adaptive plant defense mechanism against water stress (Sinclair et al., 2004; Inman-Bamber et al., 2012).

The number of stalks per linear meter increased in RB855113 and SP79-1011 during the ripening stage when these varieties were under water stress. These results suggest that RB855113 and SP79-1011 became overloaded and could not produce enough energy to grow stalks because their energy was used in tiller formation. Such process may have led to delayed sucrose accumulation in the stalk and, consequently, to decreased yield. According to Inman-Bamber et al. (2009), high sugarcane tillering rates generate a large amount of new leaves and it may cause photoassimilates displacement to new plant structures, low sucrose production, delayed accumulation in the stalks and reduced plant yield.

The larger number of RB92579 plants per linear meter and their high yield depicts their good vigor, even under water deficit conditions. Oliveira et al. (2010) studied the growth and yield of 11 sugarcane varieties subjected to full irrigation and found higher tillering rates in the RB92579 variety. Zhao et al. (2013) also showed that this variety was the most tolerant to drought and the one presenting the best tillering rates under water stress. According to these authors, tillering and stalk length can be useful indicators to early detect water stress and to assess the most water-stress tolerant sugarcane genotypes.

The ability of a certain species to develop in dry soils can be determined by its efficiency to adjust its morphophysiological behavior, e.g., higher sugarcane leaf-area indices indicate high photosynthetic efficiency (Sinclair et al., 2004; Oliveira et al., 2004). Variety RB92579 recorded the biggest leaf area in all the assessed phenophases in all the herein analyzed varieties; moreover, this variety kept the same records when it was under water stress, although it did not differ from the other varieties. According to Endres et al. (2010), RB92579 has a good water absorption system even when it is subjected to water deficit, thus this variety has a tolerance mechanism to withstand drought rather than to prevent it. Varieties RB855536 and RB72454 recorded the smallest leaf areas, mainly when they were under water stress during the intense growth stage. Such low leaf area 
Table 1. Stalk yield in tons per hectare (SYH), quality of sugar raw material, total soluble solids (BRIX), fiber content (FIBER) and total recoverable sugar (TRS) in sugarcane varieties subjected to two water regimes: irrigation and drought.

\begin{tabular}{lccccc}
\hline Varieties & Treatment & $\begin{array}{c}\text { SYH } \\
(\mathrm{t} / \mathrm{ha})\end{array}$ & $\begin{array}{c}\text { BRIX } \\
(\%)\end{array}$ & $\begin{array}{c}\text { FIBER } \\
(\%)\end{array}$ & $\begin{array}{c}\text { TRS } \\
\text { (kg TRS / ton) }\end{array}$ \\
\hline SP79-1011 & Irrigation & $109.1 \mathrm{a}^{*}$ & $19.6 \mathrm{a}$ & $14.5 \mathrm{a}$ & $134.8 \mathrm{a}$ \\
& Drought & $77.4 \mathrm{~b}$ & $19.0 \mathrm{a}$ & $13.5 \mathrm{a}$ & $134.2 \mathrm{a}$ \\
$\mathrm{RB}$ & Irrigation & $127.9 \mathrm{a}$ & $20.5 \mathrm{a}$ & $13.6 \mathrm{a}$ & $144.7 \mathrm{a}$ \\
& Drought & $98.2 \mathrm{~b}$ & $20.3 \mathrm{a}$ & $13.3 \mathrm{a}$ & $143.5 \mathrm{a}$ \\
$\mathrm{RB867515}$ & Irrigation & $125.7 \mathrm{a}$ & $20.2 \mathrm{a}$ & $13.9 \mathrm{a}$ & $140.0 \mathrm{a}$ \\
& Drought & $88.5 \mathrm{~b}$ & $19.5 \mathrm{a}$ & $13.6 \mathrm{a}$ & $135.0 \mathrm{a}$ \\
$\mathrm{RB72454}$ & Irrigation & $108.6 \mathrm{a}$ & $20.6 \mathrm{a}$ & $14.1 \mathrm{a}$ & $144.6 \mathrm{a}$ \\
& Drought & $54.3 \mathrm{~b}$ & $20.2 \mathrm{a}$ & $13.9 \mathrm{a}$ & $140.3 \mathrm{a}$ \\
$\mathrm{RB}$ & Irrigation & $93.0 \mathrm{a}$ & $19.8 \mathrm{a}$ & $14.0 \mathrm{a}$ & $137.4 \mathrm{a}$ \\
& Drought & $60.3 \mathrm{~b}$ & $19.8 \mathrm{a}$ & $14.3 \mathrm{a}$ & $138.3 \mathrm{a}$ \\
$\mathrm{RB} 8555113$ & Irrigation & $94.2 \mathrm{a}$ & $21.0 \mathrm{a}$ & $13.3 \mathrm{a}$ & $146.7 \mathrm{a}$ \\
& Drought & $72.2 \mathrm{~b}$ & $19.1 \mathrm{~b}$ & $13.8 \mathrm{a}$ & $133.0 \mathrm{~b}$ \\
& Irrigation & $109.8 \mathrm{a}$ & $20.3 \mathrm{a}$ & $13.9 \mathrm{a}$ & $141.4 \mathrm{a}$ \\
& Drought & $75.1 \mathrm{~b}$ & $19.6 \mathrm{~b}$ & $13.7 \mathrm{a}$ & $137.4 \mathrm{~b}$ \\
\hline${ }^{*}$ Means followed by the same letter in the same column within each variety were not significantly different in the Tukey's test at 5\% probability.
\end{tabular}

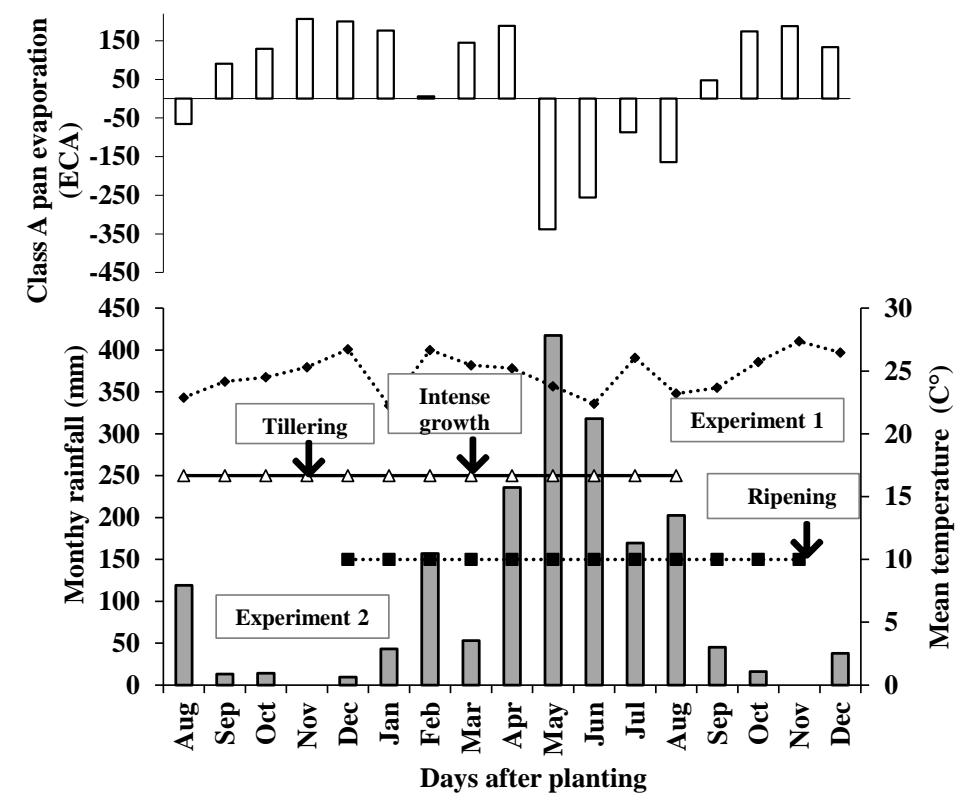

Fig 1. Class A pan evaporation ( $\square$ ), monthly total rainfall ( $\square$ ), mean air temperature $(\triangleleft)$ during the experiment (Source: Agritempo, 2016). Arrows indicate monthly total rainfall in the months phenophases were assessed: tillering (November), intense growth (March) and ripening stages (November).

Table 2. Drought tolerance index in sugarcane varieties subjected to drought and irrigation in the field: stress susceptibility index (SSI), drought tolerance index (DTI) and yield/tolerance index (YTI) calculated according to sugar yield.

\begin{tabular}{lll}
\hline Variety & $\mathrm{DTI}$ & $\mathrm{YTI}$ \\
\hline RB72454 & $0.73 \mathrm{e}^{*}$ & $0.49 \mathrm{e}$ \\
$\mathrm{RB} 855113$ & $1.12 \mathrm{a}$ & $0.56 \mathrm{~d}$ \\
$\mathrm{RB} 855536$ & $0.95 \mathrm{~d}$ & $0.47 \mathrm{f}$ \\
$\mathrm{RB} 867515$ & $1.03 \mathrm{c}$ & $0.92 \mathrm{~b}$ \\
RB92579 & $1.12 \mathrm{a}$ & $1.04 \mathrm{a}$ \\
* & $1.04 \mathrm{~b}$ & $0.70 \mathrm{c}$ \\
\cline { 2 - 3 } Means followed by the same letter in the same column were not significantly different in the Tukey's test at 5\% probability.
\end{tabular}




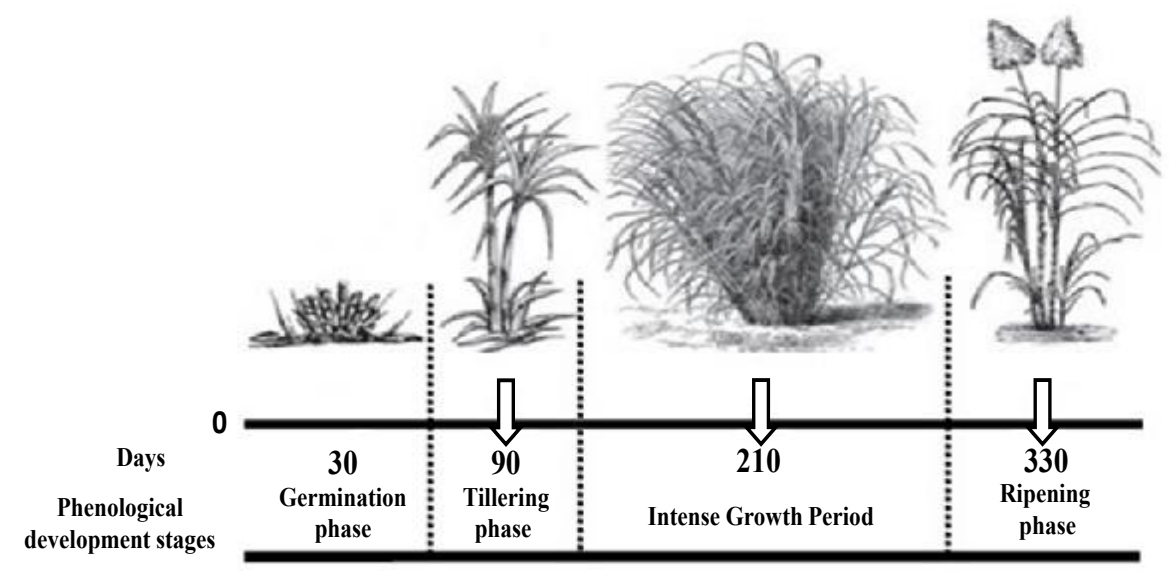

Fig 2. Phenological stages of the sugarcane crop. Arrows indicate plant-development age and the herein assessed phenophases. Adapted from Aguilar-Rivera et al. (2015).
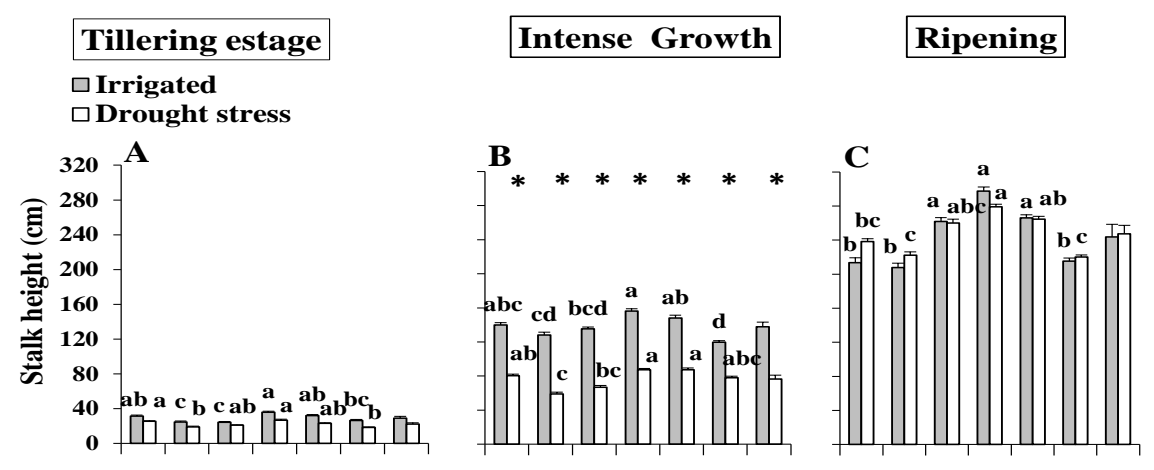

D
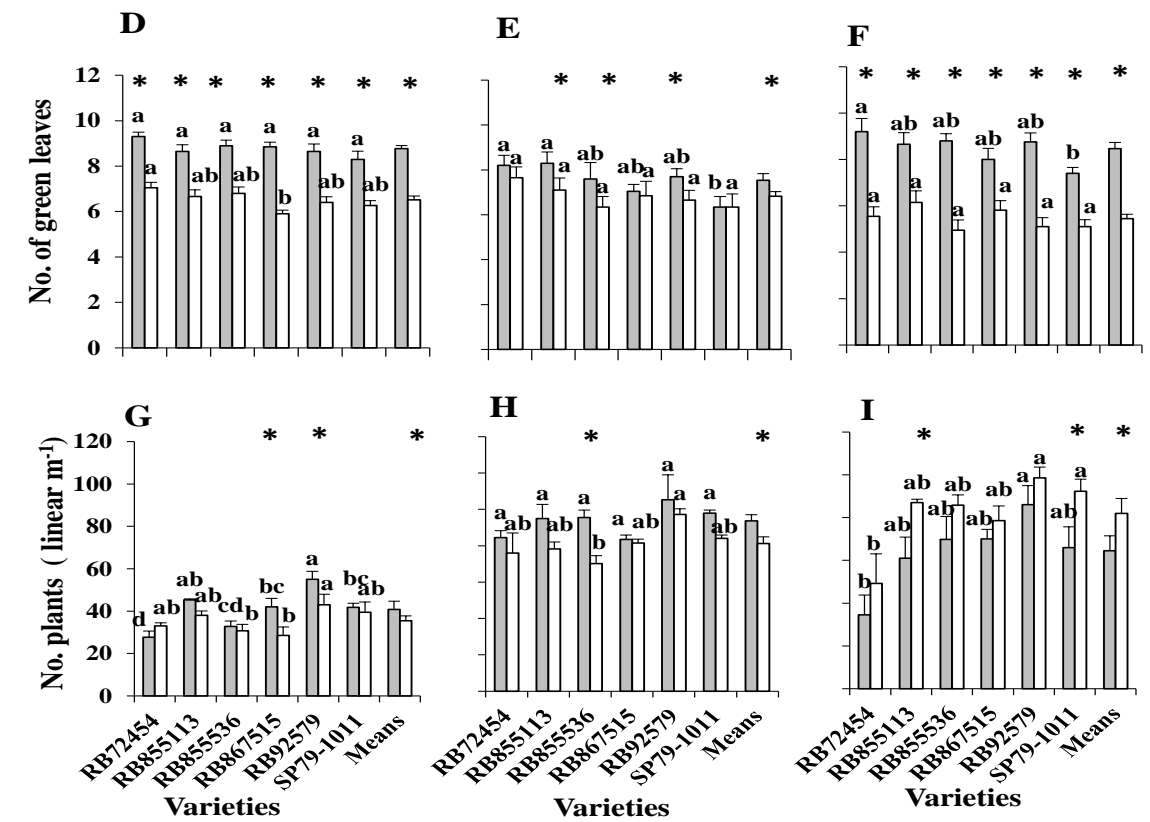

Fig 3. Stalk height $(A, B, C)$, green-leaf number $(D, E, F)$ number of plants per linear meter $(G, H, I)$ in sugarcane varieties under two water regimes: irrigation and drought, measured at the three phonological stages: tillering $(A, D, G)$, intense growth $(B, E, H)$ and ripening $(C, F, I)$. Means on columns with the same color (treatment) and with the same letter are not significantly different in the Tukey's test at $5 \%$ probability. Asterisks indicate that the differences between the irrigation and the drought treatments in each variety differ in the $\mathrm{F}$ test at $5 \%$ probability. 


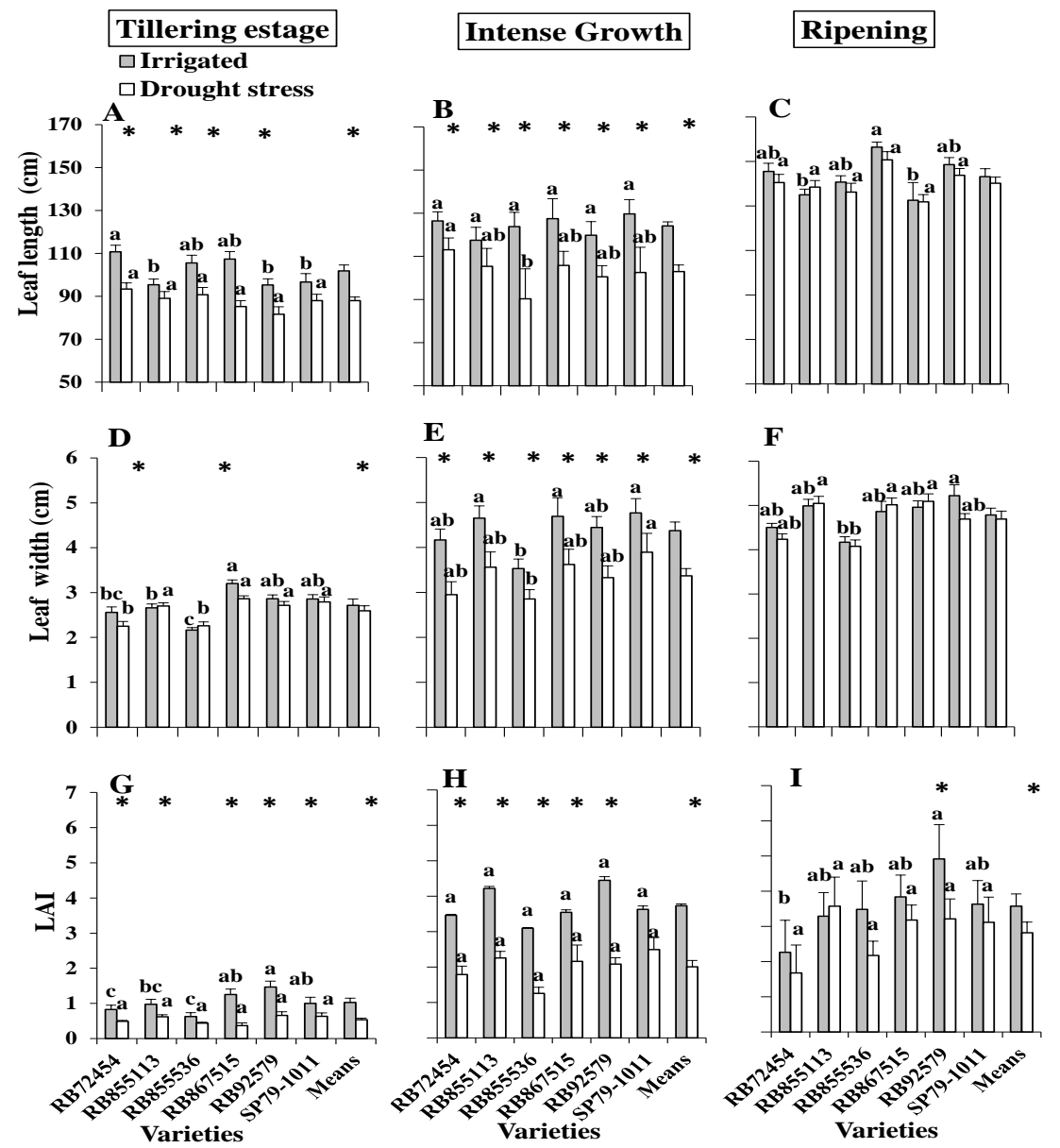

Fig 4. Leaf length $(A, B, C)$, leaf width $(D, E, F)$, leaf area index, $L A l,(G, H, I)$ in sugarcane varieties subjected to two water regimes: irrigation and drought, measured at three phenological stages: tillering $(A, D, G)$, intense growth $(B, E, H)$, and ripening $(C, F, I)$. Means on columns in the same color and with the same letter were not significantly different in the Tukey's test at $5 \%$ probability. Means on columns in the same variety superscripted by * differed in the $\mathrm{F}$ test at $5 \%$ probability.

$\square$ Irrigated $\square$ Drought stress
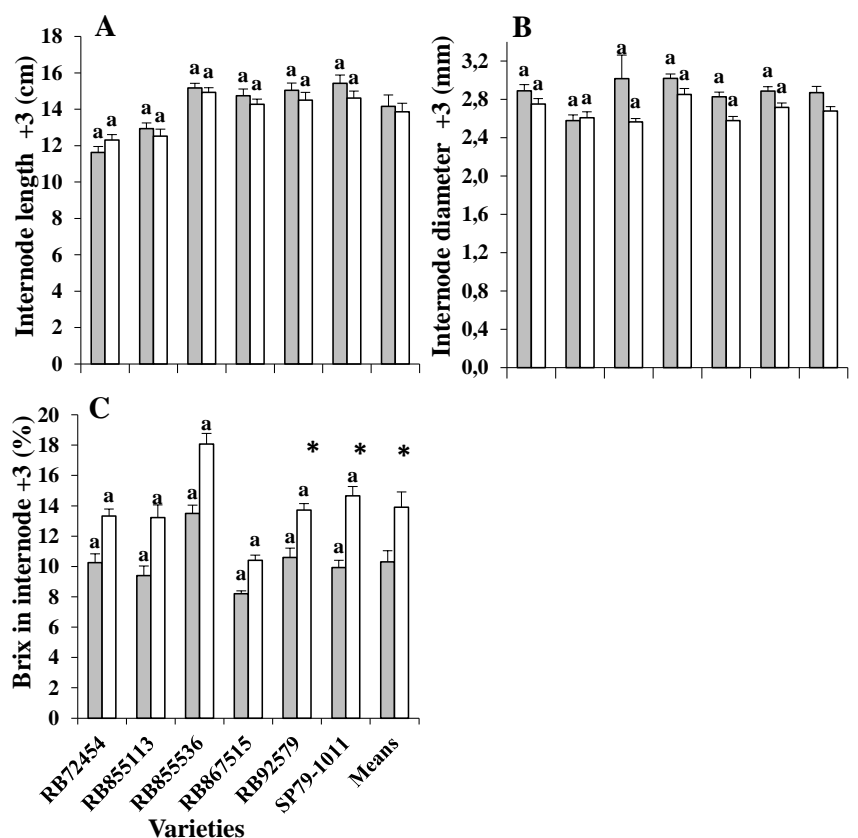

Fig 5. Internode length $+3(A)$, internode diameter $+3(B)$, and brix in internode $+3(C)$ in the ripening phenophase in the sugarcane varieties assessed under two water regimes: irrigation and drought. Means on columns in the same color and with the same letter were not significantly different in the Tukey's test at $5 \%$ probability. Means on columns in the same variety superscripted by $*$ differed in the $\mathrm{F}$ test at $5 \%$ probability. 

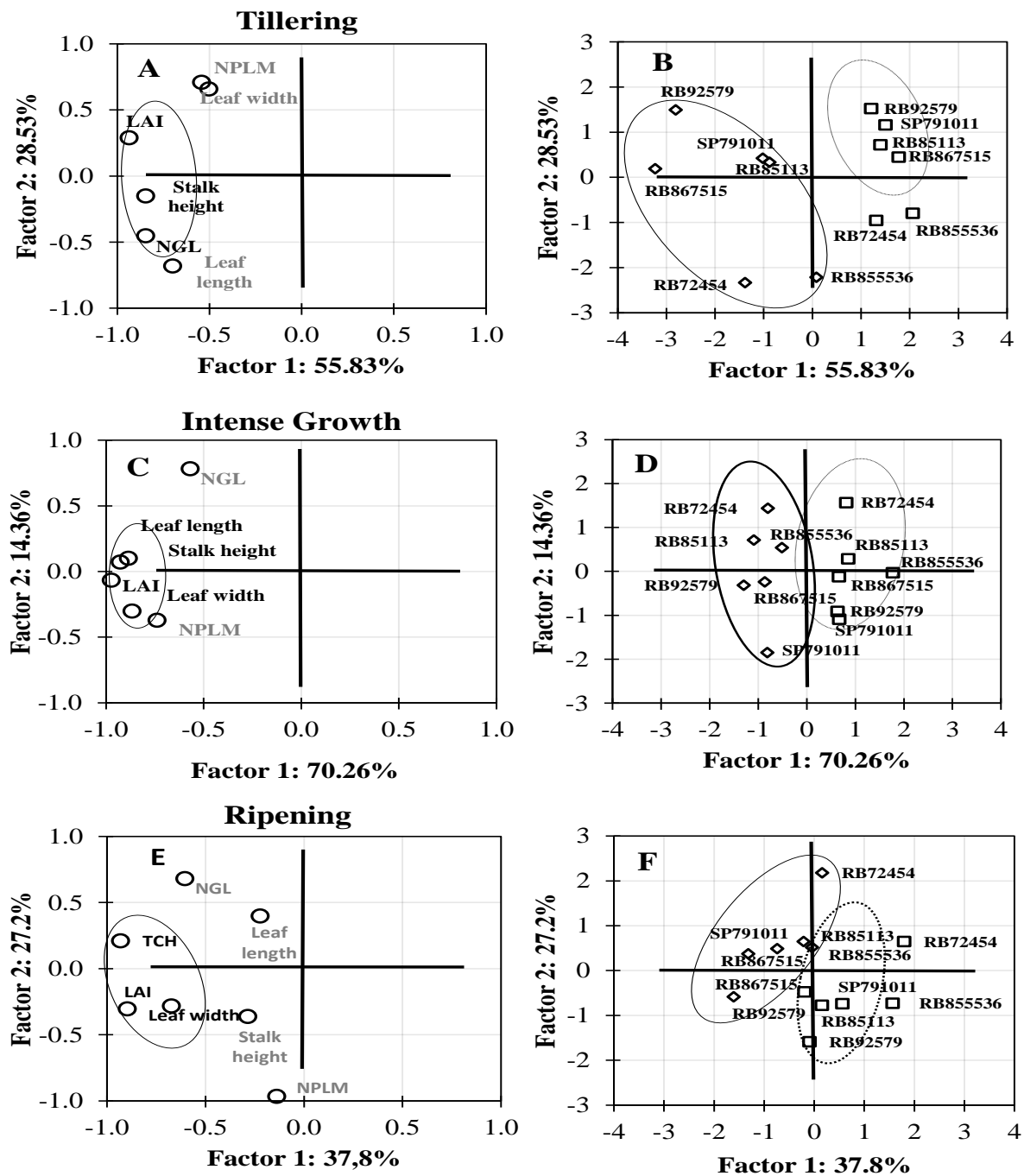

Fig 6. Principal component analysis applied to six sugarcane varieties subjected to two water regimes: irrigation $(0)$ and drought $(\square)$, measured at three phenological stages: tillering $(A, B)$, intense growth $(C, D)$, and ripening $(E, F)$, by taking into considera tion the principal component analysis (CP1 and CP2), which corresponded to six physiological variables: leaf length, leaf width (LW), stalk height, number of green leaves (NGL), number of plants per linear meter (NPLM), leaf area index (LAI), and stalk yield in tons per hectare $(\mathrm{TCH})$.

index suggests that these varieties are more sensitive to prolonged drought periods than other varieties; therefore, RB855536 and RB72454 are able to withstand drought by getting rid of their own leaves. Other studies about sugarcane plants subjected to water deficit in the field (Inmam-Bamber and Smith, 2005; Farias et al., 2008; Silva et al., 2015) and in greenhouses (Machado et al., 2009; Zhao et al., 2013; Santos et al., 2015) also evidenced that varieties more sensitive to drought present reduced leaf mass and area.

Although irrigated SP79-1011 plants did not present big leaf area, they recorded one of the biggest leaf areas when they were under water stress. This characteristic may due to the high ability shown by the variety to curl its leaves (data not shown). Such ability is a mechanism to escape drought and reduce water loss (Inman-Bamber et al., 2012).

Soluble-solids concentration in internode +3 increased under water deficit conditions. Variety RB855536 presented the highest soluble-solids concentrations and one of the lowest height growth and sugar production rates. According to this result, RB855536 was strongly affected by water deficit conditions.

Variety RB855113 was the only one to have its industrial yield affected by water deficit, and it suggests that drought reduced its genetic potential. Results such as reduced total Brix levels, corrected Pol and reduced sugar rate, mainly in sugar production per hectare (which evidences low rawmaterial quality), evidenced sucrose accumulation in the stalks (Oliveira et al., 2011). The highest rates of total soluble-solids and sugarcane Pol evidenced that RB92579 produced stalks of high technological quality, even when it was under water stress. At the same time, this variety presented high stalk production, which resulted in high sugar amounts per hectare. Studies on sugarcane plants grown in different regions address that the varieties presenting high purity and Brix rates also have high sucrose concentration in the stalk, fact that leads to high yield in industrial production lines (Oliveira et al., 2011; Guo et al., 
2014; Silva et al., 2015). Varieties RB92579 and RB867515 recorded the highest stalk yield per hectare, even when they were under water deficit conditions. Oliveira et al. (2011) also assumed that these varieties are the most productive ones in dry environments and the most water-use efficient species. Moreover, they are the most productive varieties in savanna regions where drought is common (Campos et al., 2014). Despite being one of the most productive varieties under irrigation, RB72454 was the least productive variety under water stress. It also presented the lowest drought tolerance index (DTI), fact that also proved its susceptibility to water deficit. Sugarcane varieties sensitive to drought tend to present high yield decrease when they are under water stress (Silva et al., 2008; Begum and Islam, 2012; Basnayake et al., 2012). The best yield performance of RB92579 under water stress and irrigation led to the highest increase in drought tolerance (DTI) and yield/tolerance indices (YTI) among the assessed varieties; thus, it suggested that RB92579 can be grown in sites presenting systemic water shortage. According to Ober et al. (2004), DTI and YTI are associated with yield potential, which remains significant even when the plant is subjected to drought. According to these authors, genotypes presenting high DTI and YTI must have some characteristics, such as the ability to keep carbon assimilation and higher stomatal aperture under water stress, which prevent them from losing yield in times of drought. Endres et al. (2010) found that RB92579 keeps the stomata opened even when its leaf-water potential is lower than in other varieties. Their result suggests that the species' root system is more developed, and that such development allows water absorption from deeper soil layers.

Leaf area index, plant height, and yield were the morphological characteristics presenting the highest variability among varieties assessed through principal component analysis. The most sensitive plants (RB72454 and RB855536) in the group subjected to the worse water stress conditions were selected. This result is an important highsensitivity indicator for the aforementioned varieties when they are under water stress. Ali et al. (2015) studied corn genotypes subjected to water stress; they applied the principal component analysis and found that leaf number, plant height and leaf area were the most evident morphological characteristics available to select the most water-deficit tolerant groups. The same principal component analysis also showed that the biomass and relative growth rates were effective morphological characteristics used to distinguish the most drought-tolerant cocoa genotypes (Santos et al., 2014).

\section{Materials and methods}

\section{Plant material}

The six most cultivated sugarcane (Saccharum ssp.) varieties in the region, namely: SP79-1011, RB855113, RB92579, RB867515, RB72454, and RB855536, were chosen to be the study object in the present research.

\section{Study site description and climatological characteristics}

The experiment was conducted under field conditions in Campo Alegre County, Alagoas State, Brazil ("9o45'32" S, 3613'09 "W), at mean altitude 170 meters. The climate in the region is tropical rainy with dry summer, and two welldefined seasons: dry season with scattered showers for seven months (from September to March); and five-month rainy season (from April to August) - mean annual rainfall reaches $1,634.2 \mathrm{~mm}$. The rainfall accumulated throughout the study period was $1,851.0 \mathrm{~mm}$, and the mean temperatures ranged from $22^{\circ} \mathrm{C}$ to $28^{\circ} \mathrm{C}$ (Fig 1). Monthly rainfall, mean temperature and Class $\mathrm{A}$ tank evaporation (CAE) data (Fig 1) were recorded during the experiment, as well as the data provided by Agritempo (2016).

The maximum monthly rainfall rate was recorded in May $(417.5 \mathrm{~mm})$, and the minimum monthly rainfall rate $(0.0 \mathrm{~mm})$ was recorded in November (Fig 1). The thermal amplitude in the region was low; mean temperatures ranged from 22.2 ㅇ C to $27.5 \stackrel{\circ}{\circ} \mathrm{C}$ in the dry season, and from 22.4 으 $\mathrm{C}$ to 26.0 으 $\mathrm{C}$ in the rainy season (Fig 1). The rainfall accumulated during the sugarcane tillering-phenophase month was $0.0 \mathrm{~mm}$; and during the intense growth phenophase, it was $53 \mathrm{~mm}$, and $0.0 \mathrm{~mm}$ in the ripening phenophase (Fig 1). These rainfall levels evidenced that the crop was under water deficit.

\section{Experimental design}

The present study followed a randomized block experimental design (6x2 factorial - six sugarcane varieties and two water regimes) with four repetitions per treatment and assessed three phenological stages. The plots comprised five 8-m long rows (grooves), which were spaced $1 \mathrm{~m}$ away from each other, thus totaling $40 \mathrm{~m}^{2}$ per plot; only the three central rows were considered useful for morphological analysis purposes.

The sugarcane phenological stages chosen to be assessed during the dry season followed the description by Gasho and Shih (1983). Plants were assessed in three different phenophases after planting: 1) tillering stage and crop establishment ( 3 month-old plants), 2) intense growth and stalk elongation ( 7 month-old plants), and 3 ) ripening (11 month-old plants) (Fig 2).

Sugarcane planting was performed in two stages to enable assessing the different phenophases during the dry season in the same region. The varieties were distributed in two experimental sites located close to each other. The first planting carried out in the first site was performed in August and its plants were assessed in November $(3$ months after planting), as well as in March of the following year (7 months after planting), because these months correspond to the dry season (Fig 1). Varieties tested in the present experiment were harvested 12 months after sowing, when they were at ripening stage; their yield was estimated after harvest. The second planting, which was performed in a nearby site, was carried out in December of the same year. The development of plants sown in December was followed up until the stalk ripening phase (11 months after planting); the assessments were conducted in November, also during the dry season (Fig 1).

\section{Drought and irrigation regimes}

The water regimes were irrigation and water deficit. These regimes were imposed to the chosen varieties during three phenological stages, namely: tillering, intense growth and ripening. Plants were irrigated with $50 \mathrm{~mm}$ of water during the dry months in the irrigation treatment, whereas non- 
irrigated plants naturally developed under water deficit conditions throughout the experiment.

\section{Morphological assessments}

Data from randomly chosen plants located in the three central rows of each plot were collected. Ten plants were chosen to have their stalk height, green-leaf number, length and leaf +3 width, leaf area index (LAI) and number of plants per linear meter assessed. Stalk height was measured from the plant base (close to the ground) to ligular leaf +1 . The leaf area index (LAI) was quantified in a Plant Canopy Analyzer (model LAI-2000 LI-COR).

Internode +3 from leaf +1 insertion in the third phenophase (ripening) was chosen to set the length $(\mathrm{cm})$, diameter $(\mathrm{mm})$ and sugarcane juice Brix. Length and diameter were measured with the aid of a ruler and a caliper, respectively; the soluble-solids content was set in digital refractometer (Hanna Instruments, USA).

\section{Raw material quality and yield analysis}

Stalk yield in tons per hectare (SYH) was recorded 12 months after sowing by harvesting the plants in the three central rows $\left(24 \mathrm{~m}^{2}\right)$ of each plot; the weight was quantified on a graduated load cell scale (capacity $=200 \mathrm{~kg}$ ).

Ten stalks from each plot were randomly chosen for rawmaterial quality analysis according to recommendations by CONSECANA (2006): fiber content in cane (\% FIB), total soluble solids (BRIX) and total recoverable sugars (TRS, kg/t).

\section{Drought tolerance index}

The drought tolerance index (DTI) rate was similar to the stress susceptibility index, according to the method by Fischer and Maurer (1978), adapted by Ober et al. (2004). The DTI was calculated through the following equation: DTI = $(\mathrm{YD} / \mathrm{YI}) /(\hat{\mathrm{Y} D} / \hat{\mathrm{Y} I})$. Wherein: $\mathrm{YD}$ and $\mathrm{YI}$ are the genotype yields (or biomass) under drought and irrigation conditions, respectively; and $\hat{Y} D$ and $\hat{Y}$ l are the mean yields (or biomass) of all genotypes under drought and irrigation conditions, respectively.

The yield tolerance index (YTI) was calculated according to Fernandez (1992), who combined the relative performance of a genotype under drought conditions to its potential yield under irrigation conditions: $\mathrm{YTI}=(\mathrm{YD} / \mathrm{YI}) /(\hat{\mathrm{Y} I})^{2}$

\section{Statistical analysis}

The results were subjected to analysis of variance and the treatment means were compared by Tukey test at 5\% probability. The principal component analysis (PCA) was performed based on the morphological variables of the sugarcane variety in different phenophases (sprouting, intense growth, and ripening), as well as on yield. The analysis was applied to each phenophase and conducted in the Statistica v10 software.

\section{Conclusion}

Sugarcane varieties are mostly affected by water stress during the intense growth and stalk elongation phenophases. Plant height, leaf length, green-leaf number, and leaf area are potential reliable morphological indicators to select the most water-deficit tolerant sugarcane varieties. Moreover, the principal component analysis showed that yield is also an important indicator to distinguish the most tolerant varieties.

Drought tolerance and yield/tolerance indices are suitable to identify the most water-deficit tolerant sugarcane varieties, as well as the varieties presenting the highest yield under water stress.

Variety RB92579 presented the highest drought tolerance potential; therefore, it can be recommended as the standard variety for genetic enhancement programs focused on identifying the most drought-tolerant hybrids; moreover, it can be a rich source of high biotechnological potential genes. Varieties RB72454 and RB855536 should not be recommended for environments where water stress periods are frequent.

\section{Acknowledgment}

The authors would like to thank the National Council for Scientific and Technological Development (CNPq - Brazil), the Coordination for the Improvement of Higher Education Personnel (CAPES - Brazil) and the Research Support Foundation of Alagoas State (FAPEAL - Brazil) for their financial support.

\section{References}

AGRITEMPO (2016) Sistema de monitoramento http://www.agritempo.gov.br. Accessed in August 2016.

Aguilar-Rivera N, Siller MA, Vargas LAO (2015) Gestión del agua como factor limitante de productividad cañera en México. Rev Geogr Norte Gd. 60: 135-152.

Ali F, Kanwal N, Ahsan M, Ali Q, Bibi I, Niazi NK (2015) Multivariate analysis of grain yield and its attributing traits in different maize hybrids grown under heat and drought stress. Scientifica. 2015:1-6.

Anwar J, Subhani GM, Hussain M, Ahmad J, Hussain M, Munir M (2011) Drought tolerance indices and their correlation with yield in exotic wheat genotypes. Pak J Bot. 43 (3): 1527-1530.

Bailey NTJ (1959) Statistical Methods in Biology. English University Pess, London, 48p.

Basnayake J, Jackson PA, Inman-Bamber NG, Lakshmanan P (2012) Sugarcane for water-limited environments. Genetic variation in cane yield and sugar content in response to water stress. J Exp Bot. 63 (16): 6023-6033.

Begum MK, Islam MS (2012) Effect of drought stress on yield and yield components of sugarcane. J Agrofor Environ. 6(1): 105-109.

Câmara GMS (1993) Ecofisiologia da cultura da cana-de-açúcar. In: Câmara GMS, Oliveira EAM (Eds). Produção da cana-deaçúcar. FEALQ, Piracicaba. P.31-64.

Campos PF, Alves JJ, Casaroli D, Fontoura PR, Evangelista AWP, Vellame LM (2014) Response of sugarcane varieties to deficit irrigation in Brazilian Savanna. WRIM. 3 (5): 31-36.

Carvalho AL, Menezes RSC, Nóbrega RS, Siqueira Pinto A, Ometto JPHB, von Randow C, Giarolla A (2015) Impact of climate changes on potential sugarcane yield in Pernambuco, northeastern region of Brazil. Renew Energy. 78: 26-34.

Conab - Companhia nacional de abastecimento (2015) Acompanhamento de safra brasileira cana-de-açúcar. Safra 2015/2016, n. 3 - Terceiro Levantamento, Brasília. 2: 1-65. 
Consecana (2006) Manual de Instruções. 5 ed. Piracicaba: Conselho dos Produtores de Cana-de-Açúcar, Açúcar e Álcool do Estado de São Paulo. 115p.

Dillewijn CV (1952) Botany of sugarcane. Walthham: Chonica Botanica. 371p.

Endres L, Silva JV, Ferreira VM, Barbosa GVS (2010) Photosynthesis and water relations in Brazilian sugarcane. The Open Agric J. 4 (3): 31-37.

Fao (2016) Report, Food and Agricultural Organization, United Nations: Economic and Social Department. Available at: http://www.fao.org/about/en. Accessed in September 2016.

Farias CHA, Fernandes PD, Azevedo HM, Dantas Neto J (2008) Índices de crescimento da cana-de-açúcar irrigada e de sequeiro no Estado da Paraíba. Rev Bras Eng Agríc Ambient. 12 (4): 356-362.

Fernandez GCJ (1992) Effective selection criteria for assessing plant stress tolerance. In: Kuo CG (Ed). Adaptation of Food Crops to Temperature and Water Stress, Publication Number. 93-410. Asian Vegetable Research Development Center, Shanhua, Taiwan. 257-270.

Fischer RA, Maurer R (1978) Drought resistance in spring wheat cultivars. I. Grain yield response. Aust J Agric Res. 29 (5): 897907.

Gascho GJ, Shih SF (1983) Sugarcane. In: Teare ID, Peet MM (Ed). Crop-water relations. New York: Wiley-Interscience. 445-479.

Gentile A, Dias LI, Mattos RS, Ferreira TH, Menossi M (2015) MicroRNAs and drought responses in sugarcane. Front Plant Sci. 6: 1-58.

Guimaraes CGG, Oliveira RC, Teixeira MB, Dorneles MS, Domingos RMO, Megguer CA (2014) Sugar cane crop coefficient by the soil water balance method. Afr J Agric Res. 10 (24): 2407-2414.

Guo J, Ling H, Wu Q, Xu L, Que Y (2014) The choice of reference genes for assessing gene expression in sugarcane under salinity and drought stresses. Sci Rep. 4: 7042.

Hemaprabha G, Swapna S, Lavanya DL, Sajitha B, Venkataramana S (2013) Evaluation of Drought Tolerance Potential of Elite Genotypes and Progenies of Sugarcane (Saccharumsp. hybrids). Sugar Tech. 15 (1): 9-16.

Inman-Bamber NG (2004) Sugarcane water stress criteria for irrigation and drying off. Field Crops Res. 89 (1): 107-122.

Inman-Bamber NG, Bonnett GD, Spillman MF, Hewitt ML, Xu J (2009) Source-sink differences in genotypes and water regimes influencing sucrose accumulation in sugarcane stalks. Crop Pasture Sci. 60 (4): 316-327.

Inman-Bamber NG, Lakshmanan P, Park S (2012) Sugarcane for water-limited environments: theoretical assessment of suitable traits. Field Crops Res. 134: 95-104.

Inman-Bamber NG, Smith DM (2005) Water relations in sugarcane and response to water deficits. Field Crops Res. 92 (2): 185-202.

Larcher W (2004) Ecofisiologia Vegetal. São Carlos: Rima artes. 531p.

Machado RS, Ribeiro V, Marchiori PER, Machado DFSP, Machado EC, Landell MGA (2009) Respostas biométricas e fisiológicas ao déficit hídrico em cana-de-açúcar em diferentes fases fenológicas. Pesq Agropec Bras. 44 (12): 1575-1582.

Menezes CB, Ticona-Benavente CA, Tardin FD, Cardoso MJ, Bastos EA, Nogueira DW, Schaffert RE (2014) Selection indices to identify drought-tolerant grain sorghum cultivars. Genet Mol Res. 13(4): 9817-9827.

Ober ES, Clark CJ, Bloa ML, Royal A, Jaggard KW, Pidgeon JD (2004) Assessing the genetic resources to improve drought tolerance in sugar beet: agronomic traits of diverse genotypes under droughted and irrigated conditions. Field Crops Res. 90 (2): 213-234.
Oliveira AD, Simões Neto DE, Rocha A, Carvalho L (2011) Produtividade, eficiência de uso da água e qualidade tecnológica de cana-de-açúcar submetida a diferentes regimes hídricos. Pesq. Agropec. bras. 46 (6): 617-625.

Oliveira ED, Freire FJ, Oliveira AD, Simões Neto DE, Rocha A, Carvalho L (2011) Crescimento e acúmulo de matéria seca em variedades de cana-de-açúcar cultivadas sob irrigação plena. Ver Bras Eng Agríc Ambient. 14 (9): 951-960.

Oliveira RA, Daros E, Zambon JLC, Weber H, Ido OT, ZufellatoRibas, Koehler HS, Silva DKT (2004) Crescimento e desenvolvimento de três cultivares de cana-de-açúcar, em cana-planta, no estado do Paraná: taxas de crescimento. Sci Agric. 5 (1): 87-94.

Pincelli RP, Silva MA (2012) Alterações morfológicas foliares em cultivares de cana-de-açúcar em resposta à deficiência hídrica. Bios Jour. 28 (4): 546-556.

Ramesh P, Mahadevaswamy M (2000) Effect of formative phase drought on different classes of shoots, shoot mortality, cane attributes, yield and quality of four sugarcane cultivars. J Agron Crop Sci. 185 (4): 249-258.

Santos CM, Silva AM, Lima GPP, Bortolheiro FPDAP, Brunelli MC, Holanda LA, Oliver R (2015) Physiological Changes Associated with Antioxidant Enzymes in Response to Sugarcane Tolerance to Water Deficit and Rehydration. Sugar Tech. 17 (3): 291-304.

Santos IC, Almeida AAF, Anhert D, Conceição AS, Pirovani CP, Pires JL, Baligar VC (2014) Molecular, physiological and biochemical responses of theobroma cacao L. Genotypes to Soil Water Deficit. Plos One. 9 (12): 115746.

Silva MA, Arantes MT, Hein A, Pincelli RP, Santos CM, Moura PCS (2015) Características morfofisiológicas e produtividade de cana-de-açúcar variam de acordo com a cultivar e o regime hídrico. Irriga. 1 (1): 160-177.

Silva MDA, Silva JAGD, Enciso J, Sharma V, Jifon J (2008) Yield components as indicators of drought tolerance of sugarcane. Sci. agric. 65 (6): 620-627.

Silva VDP, De Oliveira SD, Santos CA, Silva MT (2013) Risco climático da cana-de-açúcar cultivada na região Nordeste do Brasil. Rev bras eng agríc ambient. 17 (2): 180-189.

Sinclair TR, Gilbert RA, Perdomo RE, Shine JR. JM, Powell G, Montes G (2004) Sugarcane leaf area development under field conditions in Florida, USA. Field Crops Res. 88 (2): 171 178.

Smit, MA, Singels A (2006) The response of sugarcane canopy development to water stress. Field Crops Res. 98 (2): 91-97.

Souza Guimarães P, Bernini CS, Pedroso FK, Paterniani ME (2014) Characterizing corn hybrids (Zea mays L.) for water shortage by principal components analysis. Maydica. 59 (1): 72-79.

Taiz L, Zeiger E (2009) Fisiologia vegetal. 4.ed. Porto Alegre: Artmed. 819p.

Thiebaut F, Grativol C, Carnavale-Bottino M, Rojas CA, Tanurdzic M, Farinelli L, Hemerly AS, Ferreira PCG (2012) Computational identification and analysis of novel sugarcane microRNAs. BMC genomics. 13 (1): 1-14.

Uehara N, Sasaki N, Aoki N, Ohsug R (2009) Effects of the temperature lowered in the daytime and night-time on sugar accumulation in sugarcane. Plant Prod Sci. 12 (4): 420-427.

Waclawovsky AJ, Sato PM, Lembke CG, Moore PH, Souza GM (2010) Sugarcane for bioenergy production: an assessment of yield and regulation of sucrose content. Plant Biotechnol J. 8 (3): 1-14.

Zhao D, Glaz B, Comstock JC (2013) Comstock Sugarcane Leaf Photosynthesis and Growth Characters during Development of Water-Deficit Stress. Crop Sci. 53: 1066-1075.

Zhao D, LI YR (2015) Climate Change and Sugarcane Production: Potential Impact and Mitigation Strategies. Intern J Agron. 2015:1-10. 